\title{
Framing the Game: An Architectonic Analogue for Meta-Theorizing Academic Activities*
}

\author{
Brian H Spitzberg \\ Correspondence: School of Communication, San Diego State University, USA.
}

Received: January 21, 2018

doi:10.11114/smc.v6i1.2943

\author{
Accepted: February 1, 2018 \\ Online Published: March 2, 2018 \\ URL: https://doi.org/10.11114/smc.v6i1.2943
}

\begin{abstract}
A radical reformulation is proposed for explaining paradigm fragmentation. The broader topography of academic activities is conceptualized according to an academic game-theoretic analogue (GTA). According to this analogue, scholarly and academic activities reflect a competitive field of play and of plays. Criteria such as attention, compensation, awards, publications, tenure, and mobility become the scarce valued resources distributed in the game based on the plays that players enact. In an effort to reveal the heuristic potential of the theoretical analogy, these threads are traced across a broad array of humanistic and scientific theories and scholarship, including connections among Wittgenstein, Popper, Kuhn, Feyerabend, Goffman, Foucault, Bourdieu and Lyotard.
\end{abstract}

Keywords: disciplinary evolution, game theory, meta-theory, paradigm, strategic communication

"Thou art a .... Fool that seest a game play'd home, The rich stake drawn,

And takest it all for jest." (Shakespeare, The Winter's Tale, Act I, scene II)

"Academic politics are so vicious precisely because the stakes are so small." ${ }^{1}$

Proverb

The field of Communication, and its many affiliated and cognate disciplines have been charted by a wide variety of paradigm maps (e.g., Altman \& Rogoff, 1987; Anderson \& Baym, 2004; Craig, 1999; Smith, 1988). There is little doubt that the communication discipline is fragmented, multi-faceted and complex (Barnett, Huh, Kim, \& Park, 2011, p. 467). In fields such as communication (Eadie, 2011; Salomón, 2010; Stanfill, 2012), sociology (Puddephatt \& McLaughlin, 2015), political science (Blokland, 2015) and social psychology (Green, 2015), such fragmentation has been singled out as a threat to their disciplinary status and credibility. This analysis suggests an explanation for scholarly activities that provide the raw data for such variegated maps. The analogy of game theory provides a high-level explanation for academic and scholarly activities, and provides a meta-account of the raison d'etre of scholarly activity, which is to pursue such activity while seldom recognizing its game-like nature.

Disciplinary paradigms appear to be organic, ever-evolving systems of people and ideas. Kuhn (1970) proposed that paradigms may consist of very small groups, even as small as a dozen or two members, who share either similar exemplars or collective practices and beliefs. Scholarly activities are sense-making activities and language communities. As paradigms evolve, scholars often engage in sense-making to organize such paradigms along dimensions and boundaries that reflect the respective relationships among such paradigms (Foucault, 1988). Maps of these relationships represent meta-sense-making activities of these academic territories. Granting that "the map is not the territory" (Korzybski, 1931, p. 58), meta-theoretical paradigm maps are intended to bring order to the diversity of academic and scholarly activities that constitute a discipline (Charland, 2003; Wang, 2014). These organizing efforts reflect

*This manuscript was supported by the National Science Foundation: [Grant Number 1416509], IBSS project titled 'Spatiotemporal Modeling of Human Dynamics Across Social Media and Social Networks' and National Science Foundation: [Grant Number 1634641], IMEE project titled 'Integrated Stage-Based Evacuation with Social Perception Analysis and Dynamic Population Estimation'. Any opinions, findings, conclusions or recommendations expressed in this material are those of the author and do not necessarily reflect the views of the National Science Foundation.

${ }^{1}$ The proverb has many attributed origins. See: https://en.wikipedia.org/wiki/Sayre\%27s_law;

https://quoteinvestigator.com/2013/08/18/acad-politics/ 
meta-theoretical efforts, but in the process, the resulting demarcations highlight the bases for everyday enactments of administrators, professors, researchers, and students. Such maps also tend to be cast as philosophical or descriptive maps, rather than explanatory accounts (Turner, 1990).

In contrast to conceptualizing scholarly activities as a set of competing ideas or professional praxis, this inquiry posits an alternative explanatory analogue (Hawes, 1975) in which paradigms reflect strategic moves in an elaborate game or family of games. Actors compete, and their ideas are merely one set of currencies in the game. Studies and the ideas that generate them are types of plays through which more personal objectives are sought. This game analogy theorizes an explanation for ongoing paradigmatic speciation as a process that both yields personal gains for the individual player, and sustains the game and the original routine activities of those who construct and enact such theories and paradigms in their work. This analysis proceeds by articulating some basic game theoretic concepts and principles, with an eye toward the resonance between games and evolutionary processes, granting the challenges of integrating these concepts (Grüne-Yanoff, 2011).

\section{Of Paradigms and Fairy Tales}

Ford (1975) analogized paradigms as "fairy tales," or socially constructed cultural rituals. Yet, academic disciplines rarely seem to treat their work as anything but the epistemic pursuit of instruction in truths, critiques, insights and problem-solving. Disciplines generally provide an institutional structure within and across which other collective practices are enacted. These practices and collectives are referred to by a variety of terms, including those referring primarily to people (e.g., 'school' or 'field'), or to coherent systems of belief, value, or practices (e.g., 'paradigm,' 'tradition,' 'style,' 'perspective,' 'disciplinary matrix,' 'world hypotheses,' and 'world views'; see: Altman \& Rogoff, 1987; Pepper, 1957; Ritzer, Zhao, \& Murphy, 2001; Smith, 1988). All of these terms can be synopsized similarly to Kuhn's (1970) uses of the term paradigm (Hyun, 2015). Maps of these paradigms imply variegations and intersections of scholarly practices and beliefs, but such distinctions are unlikely to have emerged ex nihilo, and therefore call for theoretical conjectures on their single common feature - scholarly differentiation (Hyun, 2015).

Historians of science have formulated various primary explanations of the origins and evolution of paradigms (Guntau \& Laitko, 1991), including accounts that emphasize purely philosophical and intellectual (Laudan et al., 1986), deliberative (Czubaroff, 1989), rhetorical (Prelli, 1989), sociological and political (Lynch, 1992; Merton, 1973), and constructionist and pragmatic (Knorr-Cetina, 1999) processes. An alternative account to either a pure realist or constructionist source of paradigmatic speciation would be to view continuous theory innovation, reformulation and paradigmatic practice as a by-product of an elaborate epistemic and political game. In order to pursue this analogue, some precepts of games are in order.

\section{Framing the Game}

"A game is any situation in which the choices of two or more actors, called players, are interrelated, that is, where the outcome does not depend solely on the choice of a single actor" (Zagare \& Slantchev, 2012, p. 24). Such a game is defined in large part as "an ensemble of procedures which lead to a certain result, which can be considered in function of its principles and its rules of procedures, as valid or not, as winner or loser" (Foucault, 1987, p. 127). Games are played in some field of play (Bourdieu, 1998), which can be considered analogous to Kuhn's (1970) sociological meaning of paradigm. There are academic games (i.e., competition within paradigms) and meta-games (competition between and across paradigms).

The information state of most games is that they are incomplete and asymmetric: Players lack complete information (e.g., payoff matrix, rules) in asymmetric ways. Paradoxically, players often do not think of themselves as playing a game. This is akin to Bourdieu's (1980, p. 82) notion of a double truth of self- and collective mystification: "One can have a magnificent academic career - without ever needing to give oneself such an objective." Certain basic assumptions and implications of games for an academic analogue, include the following:

\subsection{Actor Rationality}

Individual actors (agents, players) exercise rationality within the incentive structure of the game, and in regard to the contingencies of other players' moves (tactics, strategies, styles). As part of this rationality, actors have little motivation to alter their strategic choices - that is, their rationality will typically achieve a state of equilibrium (Zagare \& Slantchev, 2012). An implication is that academic players gravitate to a familiar paradigm that seems rational to them, and may consider competing paradigms as irrational. The normal science within a paradigm, and its relative positionality vis-à-vis other paradigms, becomes normative as the equilibrium of that particular game. Several scholars have noted the increasingly hyper-competitive nature of publishing and funding incentive structures in the modern academy, even if the collective product is a suboptimal system of scientific progress (Edwards \& Roy, 2016; Smaldino \& McElreath, 2016). 
Such hyper-competitiveness may in part account for the risky moves of falsifying research (Fanelli, 2009), as well as the ever-burgeoning market that solicits research in a manner often independent of its actual quality (Bohannon, 2013).

\subsection{Equilibrium Rationality}

A particular form of equilibrium has been well-established as the Nash equilibrium (Varoufakis, 2008): "A strategy pair is a Nash equilibrium if no player can achieve a better outcome by switching, unilaterally, to another strategy" (Zagare $\&$ Slantchev, 2012). Players make moves in the game when perceived incentives indicate the value of such moves, and each move typically involves potential opportunity costs of the alternative(s) not chosen (Faria, 2005). An implication is that moves outside a given game portend potential advantages, but are also likely to involve risks. Consequently, academic players tend to stay within their own paradigm unless substantial incentives motivate speciation, changing games or game strategies.

\subsection{Within-and Between-Group Rationality}

Multiplayer games typically permit certain players to see exploitative strategies (e.g., free riders, defectors) that result in selfish benefits, which can result in systemic losses to the collective game players (e.g., tragedy of the commons, Grinell \& Rabin, 2013). Thus, multi-player groups tend to form coalitions to enforce normative compliance and punish defectors, thereby constructing a moral order for the group. Such dynamics appear to have neural substrates reflecting evolved fitness advantages for group life (Wischniewski et al., 2009). This game feature corresponds in part to Wilson and Wilson's (2007, p. 345) axiom of evolution that "selfishness beats altruism within groups. Altruistic groups beat selfish groups. Everything else is commentary." An implication is that within paradigms, academics compete fiercely to win their games, and academic players sanction players who do not contribute to, or who diminish the status of, their own affiliative groups. When those paradigms are pitted in competition with other paradigms, however, the more cohesive and internally cooperative paradigms compete better for societal attention than paradigms marked by internal fractiousness.

\section{Representation}

Games may have a variety of audiences that influence actors' rationality within the game, yet have relatively little ability to directly influence game play, except when the payoff matrix of the game is derived from the audience. An implication is that awareness of the audiences to academe is a vital element of strategic competence, especially in paradigmatic meta-games. "Scientists engage in 'boundary-work' to establish and reaffirm a positive public image for science" (Alexander \& Colomy, 1992, pp. 28-29). This impression management is important, given that in one higher education survey, over two-thirds of readers and administrators indicated they "are concerned their colleagues can 'game' or 'cheat' the systems for evaluation in their institutions" (Abbott, et al., 2010, p. 861).

\subsection{Actor Strategic Competence}

Actors vary in their political skill, competence, and breadth and depth of repertoire of tactics, strategies, and styles. Escape from domination from one truth game may be accomplished not by playing a game "totally different from the game of truth but by playing the same game differently, or playing another game, another hand, with other trump cards" (Foucault, 1997, p. 295). Those who master the game develop a "feel for the game" (Bourdieu, 1998, pp. 79-80). Furthermore, as with moral dilemmas (Graham, 1974; Medeiros et al., 2015), changes in the rules and payoffs of the game can incentivize different selections from such repertoires. These individual differences in the strategic competence of academic actors will likely reflect Paretian distributions of achievement (e.g., O’Boyle \& Aguinis, 2012).

\subsection{Strategic Competence and Actor Reflexivity}

The utility function of a game represents the "ordering, weak or strong, of aims and goals" of an actor (Goffman, 1969, p. 91). Actors' motives can be inferred with varying degrees of accuracy by their moves in the game. Furthermore, part of the competency of the game is understanding the rules of information exposure. There may be extensive common knowledge of the game being played, such that "everyone knows that everyone knows that everyone possesses certain information," but making such an "open secret explicit is taboo" (Bourdieu, 1998, p. 97). An implication is that academic activities reveal an actor's values and epistemic commitments, but the accuracy of understanding such signaling processes is differentially distributed among other actors in the discipline as a function of their strategic competence. Players may or may not believe their paradigm, and instead represent it because it is a strategic rhetorical resource.

\subsection{Strategic Competence and Game Rules}

Strategic competence (Goffman, 1969) is indexed by normative concepts of rule conformity, integrity, appropriateness, effectiveness, efficiency, or by game-defined tokens and symbolic capital such as awards, status markers or positions. These indices may be gamed to varying degrees, and may be normatively established as forms of metricization in the rules of the game. For example, one indicator of actors' strategic competence is their integrity, or their tendency "to 
remain loyal to a party once they have agreed to play for it, and not to instigate courses of action on behalf of some other party's interests, notably their own" (Goffman, 1967, p. 97). In order to thrive more than survive in the academic game "it is vital to prioritize becoming adept at the various games of academic life," which involve games of "writing particular kinds of articles or writing for particular journals; achieving promotion; working with people from other disciplines; and getting proposals funded" (Clark \& Thompson, 2013, p. 1222).

\section{Strategizing Strategic Interaction}

Thus, games are forms of strategic interaction. Strategic interaction involves two or more parties in more or less "well-structured" interaction, who act with full awareness of their interdependence on one another. "Courses of action or moves will then be made in light of one's thoughts about the others' thoughts about oneself" (Goffman, 1969, p. 101). In this "well-structured" game, and given a degree of uncertainty, stabilities will emerge that establish a normative state of play. Such a normative state of play is analogous to a given actor's style of play, as well as a Nash equilibrium (Zamora-Bonilla, 2006).

The upshot of these features of the academic game is that academic players evolve paradigms because paradigms provide reasonably predictable games within which relatively stable paths of aspiration and competency can be pursued, both individually and collectively. In Kuhn's construction, normal game play (i.e., puzzle-solving) predominates and revolutions are rare. Games occasionally become jejune as new species of theory or methodology demonstrate relative fitness in the broader meta-games of academic play, in which case, paradigm revolution (i.e., disequilibrium) may occur. Indeed, pursuing "a revolution in a field is to accord the essential of what the field tacitly demands, namely that it is important" (Bourdieu, 1998, p. 78). Short of a revolution from within, however, academic players tend to gravitate to paradigms that provide the most compatible fit for the player's apprenticed competencies or ability to shine, resulting in one source of fragmentation in academic fields of play.

\section{The Evolution(ary) Game of Academic Evolution}

The field of communication is a field of play for a game of academic activity. Academic players have different repertoires of moves at different phases of the game. As one widely acknowledged feature of playing the academic game, consider the vitae (Anonymous, 1987; Bishop, 2006; Faria, 2005; Marcoux, 2006; Motes, 1989). Scholars' vitae or collection of inscriptions constitute their book. "The game theoretic nature of scientific research arises because each scientist's payoff directly depends on what is "written' on the books of the other members of her community" (Zamora-Bonilla, 2006, p. 530).

From the game theoretic analogue (GTA), a player's book is pursued within the discipline or through interdisciplinary activities. "Everything that is valuable for scientists and can be distributed amongst alternative aims counts as a resource: Funds, positions, space for publication, time in meetings, grants, prizes, equipment, assistants, and so on" (Zamora-Bonilla, 2010, p. 305). Although "zero-sum games abound in life as well as in the lab," in the game of academe "a premier zero-sum game is getting published" (Schneider, 1992, p. 499).

Common players include actors enacting internal (teachers, administrators, students) and external (e.g., regents, regulators, legislators, taxpayers) roles. The prototypical games of Chief Academic Officers (CAOs), for example, involve using communication strategies to build internal and external coalitions, charting competitive courses for their own university vis-à-vis rival institutions and community priorities (Mulnix, Cojanu \& Pettine, 2011). The broader public or community generally plays an audience role, but is often brought into the game through various service and oversight roles.

In the process of accumulating actors' books, academic actors often become specialists in certain aspects of the game, and formulate a game strategy that capitalizes on playing a particular role in that game. For example, in the academy, actors might portray, or be perceived by others in the game as, a novice, journeyman, professional team leader, science manager, science administrator, or senior scientist (Sinderman, 1982). Other actors come to realize a rationality in which a path of least resistance may exploit the good will or cooperation of other actors in the game. Such free-riders accept the welfare of the game through strategies of camouflage (e.g., minimal attendance and volunteering) or deception (e.g., plagiarism, fluffing up a vitae; Marcoux, 1986). Other actors in the game generally will recognize the prospect of such free-riding, and will establish formal and informal processes of reciprocity involving incentives and sanctions (e.g., tenure decisions, lack of promotion). In addition, coalition groups often find themselves in a tragedy of the commons (Janssen \& Rollins, 2012), in which each player or team pursues rational selfish strategies, which collectively lead to the squandering of valued collective resources (e.g., internecine warfare within departments, administratively disbanded departments, and relative depopulation of interest groups or entire professional associations).

One of the distinct differences between intellectual or philosophical approaches to paradigms and a game theoretic 
approach is the nature of the presumed objective. A philosophical approach presupposes an objective of pursuing paradigmatic objectives, such as the revelation of reality (e.g., post-positivism) or liberation (e.g., critical theory). In contrast, from a game theoretic perspective, the most plausible common objective is that actors are playing the game to achieve and sustain a reasonable or desired standard of living for themselves (the selfish individual), their ideas (the selfish gene), or their kin (the selfish group). This standard of living may reflect tangible resources (e.g., salary, health benefits) or more self-actualizing (e.g., self-esteem, satisfaction) game objectives.

Although the academic game theoretic analogue might seem overly reductive, it is reasonable to propose that a desired standard of living may be accomplished through a variety of forms of capital accumulated through the game's payoff structure. For example, there are economic, cultural, social (Duberley \& Cohen, 2010), routine (e.g., periodic evaluation metrics; see Kelly \& Burrows, 2011), and flow or play qua play (Csikszentmihalyi, 1990) forms of capital. These reflect Bourdieu's (1998) "scholarly mode of knowledge" (p. 130) or "the ability to raise speculative problems for the sole pleasure of resolving them" (p. 128). Any of these payoffs may be instrumental to the more terminal value of a desired standard of living.

Several styles and strategies enacted in the game of academe can be conjectured, including the following as preliminary exemplars: (1) path of least resistance or free-riding (get tenure, coasting); (2) maximum visibility (quantity \& promotion), (3) stealth (flying under the radar; avoiding getting noticed), (4) administrative aspirations (grey suit power), (5) big duck in small pond (safety in comparison to weaker competitors), (6) latching on (hitching a ride on other actors' coattails), (7) entrepreneurial (seeking fame and fortune), (8) biding time (e.g., sacrificing in a disadvantageous market position in exchange for future reward; Wolfinger, Mason \& Goulden, 2009), (9) coalition formation and mobilization (security through majority-blocking capability enabled by minority factions, basking in reflected glory by association with other players), or (10) achieve and wield star status (see Aguinis \& O'Boyle, 2014; O'Boyle \& Aguinis, 2012). Stars in this context are players who demonstrate disproportionate influence by occupying or controlling game functions, maintaining status arrangements, manipulating other players, and playing more competently than others. Intellectual stars, in particular, have been characterized as enacting influential roles of grand games (e.g., Irzik \& Grünberg, 1995). These may be the players who are "well-adjusted to the game" and "are possessed by the game ... so the better they master it" (Bourdieu, 1998, p. 79). Once levels of accomplishment have been achieved through ongoing game playing, influence over the game may be facilitated by a variety of influence leveraging, including membership in an in- group, chair/director position, principle administrative office, gate-keeper office, journal editorship, journal reviewer, and regulatory positions (Sinderman, 1982). There are no doubt many other strategic orientations to be identified by future inquiry into the GTA, such as true believers, hackers or disrupters, and explorers or wanderers (e.g., Clark, 2009).

\section{Collecting Salary as You Pass "Go"}

Even though the objective of the academic GTA is personal aggrandizement and standard of living, a spandrel of this game is scholarly progressiveness. A spandrel, or exaptation, is an evolutionary offshoot, in which an organism evolves a structure or process adapted for one purpose, which then becomes re-purposed for another adaptive use (Gould \& Lewontin, 1979; Pievani \& Serrelli, 2011). In the context of the academic game, theories, publications, papers, presentations, and grants may not be an earnest search for discovery, so much as a search for status. "Truth as a product of the scientific process is different from truth as a regulating ideal that may guide epistemic activity" (Jost \& Kruglanski, 2002, p. 173). From this perspective, "science eventually yields impressive answers because it compels smart people to incessantly try to disprove the ideas generated by other smart people" (Martin, 2007, pp. 76-77). Reality becomes a "co-selector" of the results of scientific inquiry (Campbell, 1993, p. 99).

This regulating ideal may be functional for several reasons. First, having manifold players competing for innovation in scholarship likely leads to discovery along the way (Weisberg \& Muldoon, 2009). Although a closed meritocracy in some senses, the academic game is wide open to those who can play the game well, and "the more open the game, the more appealing and fascinating it becomes" (Foucault, 1997, p. 300). Second, the academic game is itself a type of "truth game" (Foucault, 1987). In playing the game in constructed domains, there are likely to be trespasses and interactions with the games of non-constructed truths (i.e., objective reality). Third, openness to multiple players playing a truth game may come close to Feyerabend's (1980) conjecture that to arrive at the truth, all possible avenues of conjecture and competition may be vital (Tsou, 2003). Even a game of random walks through a hall of mirrors is likely eventually to map out the real architectural configuration in differentiating the images from the realities. Thus, we may not have any philosophically assured epistemology to render access to the truth, but playing the game as if we do may represent an unintended spandrel of moving us closer to the truth. More importantly, it may accomplish this function better and more efficiently than alternative games that are not truth games. 


\section{Revisiting Paradigms and Fairy Tales: Re-reading Kuhn}

One implication of this spandrel hypothesis is a re-reading of Kuhn's (1970) conception of paradigms and implications for disciplinary evolution and fragmentation. Conceptualizing progressiveness (i.e., scholarly fields moving unidirectionally toward verisimilitude) may be a sense in which Kuhn (1969, p. 169) rejects the charge that he is a relativist: "Scientific development is... a unidirectional and irreversible process. Later scientific theories are better than earlier ones for solving puzzles...that is not a relativist's position." Normal science may be a game that happens to lead inexorably forward rather than backward because the game it plays is constrained by a discovery process as a primary token - that is, it is played as a truth game. Indeed, Kuhn (1970) hints at his own evolutionary conception of positivism when he argues that "an appropriately programmed perceptual mechanism has survival value" (Kuhn, 1980, p. 161).

Playing a game in which the moves of the game are constant competition of research and publication, as well as influence attempts within and across epistemic cultures, has the result of stripping away fictions and revealing the constraints of the real world to evolved senses honed by their adaptive fitness. "The world is not invented or constructed.... Creatures born into it must take it as they find it" (Kuhn, 2000, p. 101). Thus, Kuhn (2000) moves ever closer to a game spandrel perspective when he invokes the normative influence of "shared" perspectives by other actors in the game: "The essential function of the concept of truth is to require choice between acceptance and rejection of a statement or a theory in the face of evidence shared by all" (p. 99). Sometimes the normal science of playing by the rules of a paradigm achieve optimal payoffs (ala Kuhn), and sometimes breaking from one's own paradigm through revolution (ala Feyerabend) may enhance payoffs outside of the extant paradigm (Zamora-Bonilla, 2006).

To the extent that Kuhn accepts normative subjective processes that advertently and inadvertently promote progress toward the truth, it provides an avenue for drawing a common thread between Kuhn and Popper (Wray, 2011). If truth is an epistemic co-selector of scientific activities, then Popper's (1974, 1980; see also: Mayo, 1996; Walker, 2010) demarcation criterion of risky predictions and falsifiability operate not out of an ontology or bifurcation of type, but by a negotiated process of epistemological discourse games. Through such games theories may be stretched from the 'truth,' but only so far, before degrading their collective or consensual level of credibility or value in play. In this sense, a full circle begins to emerge among Popper, Kuhn, Feyerabend and Wittgenstein, in which paradigms constitute language games (Wittgenstein, 1961) and cultures (Kuhn, 2000), which collectively have the spandrel effect of progressive realization (Greenhalgh, 2015; Lynch, 1992). As Kuhn (2000) suggests, "the rules of the true/false game are ... universals for all human communities..., the result of applying those rules varies from one speech community to another" (p. 100). This may in turn reflect an effect of the 'wisdom of the crowds,' in which paradigmatic discourse regulates the degrees of deviance and reasonableness of claims (Mayo-Wilson, Zollman \& Danks, 2013; Nash, 2014; Solomon, 2006).

\section{Re-reading the Game of Scholarship and Academe}

To recapitulate, "producing knowledge capable of claiming scientific legitimacy .... is a question of playing the game of science, observing - and being seen to observe - its procedural rules and committing to its norms." Through this process "the social scientist ... deserves to be listened to because he/she has played the game" (Hynes et al., 2011, p. 298). The GTA works whether the game is taken as literal or as metaphorical. Thus, the question of whether actors are cognizant of the game they are playing is largely irrelevant to the effects of playing the game (Zamora-Bonilla, 2006). Bourdieu (1998) proposes this as a "paradox of the human sciences ... that they must constantly distrust the philosophy of action inherent in models such as game theory, which are apparently used to understand social universes resembling games" (p. 81). This paradox is resolved through a duplicity or double deception, which abandons "the theory of action as a product of an intentional consciousness, an explicit project, an explicit intention oriented toward an explicitly stated goal” (p. 97). If scholarship and academe are a game, and if the game is to act as if there are truths to be discovered, interpreted and revealed, then playing the game competently may itself be both a regulating ideal and an epistemic procedure. The game moves inexorably closer to truths, even if players (a) are often not fully aware of the larger game being played, (b) never sure in any given move exactly how much closer they come to the truth, and (c) know the game will never end, as the board and rulebook are passed onto the next generation of players.

Lyotard and Thébaud (1985, p. 61) contrasted a doctrinal approach to science that privileges one "language game above others" as "absurd." In contrast, they characterized a "pagan" approach as "the acceptance of the fact that one can play several games, and that each of these games is interesting in itself insofar as the interesting thing is to play moves." Such a pagan perspective liberates the imagination and indirectly rewards the innovation of new approaches to gaming. The value of the pagan approach is not the superiority of a given game, but that "one has several kinds of games at one's disposal. There are even some that are not invented yet and that one could invent by instituting new rules" (pp. 60-61). Thus, for example, there may be a higher-level form of strategic competence in the academic GTA - that of game designer. This particular "star" or master role might be the only role that requires a conscious awareness that the 
game is a game, a consciousness that might otherwise only episodically arise (e.g., in negotiating salaries, in promotion and tenure decisions, in job moves, etc.).

\section{The Evolutionary Implications for the Field}

The academic GTA has other disciplinary implications, especially when the game is modeled according to some basic rules of evolution. The primary engines of change and speciation of fauna are (1) natural selection and (2) sexual selection, interacting within particular ecological contexts (van Doorn, Edelaar \& Weissing, 2009). To the extent that the process of teaching and discovery represent forms of intellectual insemination, ideas and theories become the DNA of ongoing species propagation (i.e., sexual selection). These species face selective pressures from their local ecological (i.e., game or paradigm) environments, in which fitness advantages of some ideas and theories will be tested for their strategic advantage in those games. Games often incentivize development of habits that are productive for a species or group, such as academic habits that lead a tenured professor to continue being productive rather than resting on already accomplished laurels (Faria \& Monteiro, 2008).

One of the problems of Kuhn's paradigmatic revolution hypothesis is accounting for how new ideas spawn from homophilous meme pools. Where do revolutionary ideas arise from within a paradigm if everyone within that paradigm is fundamentally myopic to contrary concepts? Alexander and Colomy (1992) propose that significant challenges to a regnant paradigm "typically appear either after the founder's death or during dramatic shifts in disciplinary sensibility" (p. 44). A radical version of this hypothesis was posited by the physicist, Maxwell Planck: "A new scientific truth does not triumph by convincing its opponents and making them see the light, but rather because its opponents eventually die, and a new generation grows up that is familiar with it" (Planck, 1949, pp. 33-34).

Planck's intuition was far from mere cynical speculation. Research by Azoulay, Fons-Rosen and Graff Zivin (2015) on 452 academic life scientists who passed away at the peak of their scientific careers, found that the flow of articles by their collaborators into relevant fields decreased precipitously, but the flow of articles by non-collaborators increased by approximately $8 \%$, and these contributions subsequently were disproportionately likely to be cited highly. Intellectual vacuums appear to open ecological niches (i.e., new paradigms) into which scholars experience significant gains that were prevented by the dominance of previous regnant paradigms, or by regimes opposed to a paradigm. The exit of a top predator (i.e., highly competent strategic game player) in a given game ecosystem liberates opportunities for speciation and creativity that are no longer restrained by the existing status and paradigm structures maintained both directly and indirectly by the former stars. Further, by exiting a game, a player can strategically and paradoxically win by providing fertile ground for new species of intellectual endeavor - a genetic legacy of self-extinction by opening intellectual ecological niches for the diversity and fragmentation in which others find foothold.

Cast at a higher architectural level of the field, actors compete in their respective fields for attention and resources, this competition results in disciplinary fragmentation, resulting in an ever-progressive process of specialization, or narrowing of game roles and adaptive traits into increasingly localized intellectual ecological niches. Such specialization and fragmentation challenges resilient adaptability to changes in the intellectual environment, as the gene pool becomes vulnerable to inbreeding, and lack of adaptive fitness for radical shocks to the game's ecosystem. The communication discipline has been empirically demonstrated to be highly fragmented (Solomón, 2010) and asymmetrically porous to imported sources from other disciplines (Barnett et al., 2011; Hechter, 2003; Park \& Leydesdorff, 2009).

As a highly fragmented field, both within and across disciplinary influences, the field of communication gameplay is likely to be vulnerable to shocks, or crises, to the game, whether internal or external. Fragmentation (speciation, specialization) at the disciplinary level limits progress by creating echo chambers of inbreeding (Goldie, Linick, Jabbar \& Lubienski, 2014). In modeling the influence of truth and social influences (i.e., of other game players), Balietti et al. (2015) found in computer simulations that "at the heart of the mechanisms driving scientific progress ... [are] (i) social interactions, and (ii) peer disagreement" (p. 1). They found that fragmentation is increased and progress is "limited if the simulated scientists are open to influence only by peers with very similar views, or when within-school diversity is lost" (p. 1). There is also a spandrel implication suggested by their finding that "disciplines where the scientists received strong signals from the correct answer were less fragmented and experienced faster progress" (p. 1). The language games that develop around strong signals, or common language problems, can themselves evolve greater consensus and efficiencies in communication, and thus, greater progress (Varga, 2015). Thus, fragmentation, speciation, or specialization limits progress within species, but may propagate new species in their wakes, especially given the Planck hypothesis of innovative adaptive speciation in the event of a star's (or top predator's) extinction (death or retirement) from the game (or ecosystem). Furthermore, there may be particular paradigms, those with a regulating ideal of truth discovery, that are more prone to progress than paradigms with no such regulating game rules (Bostrom \& Donahew, 1992; Chow, 1992). "There are games of truth in which truth is a construction and others in which it is not" (Foucault, 1997, p. 297). The academic games in "hard" sciences may actually evolve faster because they have clearer signals of progress. 


\section{Getting Propositioned}

As a meta-theoretical conjecture, one of the norms of the game of traditional science calls for formalizing theory in the form of propositions. By integrating some concepts from evolutionary theory with game theory, a number of preliminary conjectures become plausible surrounding the competition for the kinds of attention valued in the academy. Scholars compete for both attention and the resources that attend to such attention (Klamer \& van Dalen, 2002). As preliminary macro-level orienting axioms, therefore, the GTA may be summarized as follows:

$\mathrm{P}_{1}$ : Positively-valenced disciplinary attention is positively related to acquisition of valued resources (Aaltio, 2009). Access to positively-valenced resources promotes resource and attention competition (Moldoveanu, 2002).

$\mathrm{P}_{2}$ : Resource competition is positively related to intra-disciplinary frictions (i.e., rhetorical aggressions, diminutions) and both intra- and inter-disciplinary competition.

$\mathrm{P}_{3}$ : Intra- and inter-disciplinary frictions are positively related to asymmetric variations in resource distribution over time.

$\mathrm{P}_{4}$ : Asymmetric intra-discipline resource distribution and intra-disciplinary competition promote scholarly fragmentation in the pursuit of positively-valenced attention. Thus,

$\mathrm{P}_{5}$ : Social scientific and humanistic fields tend toward multi-paradigmatic fragmentation more so than cohesion (Jacobs \& Frickel, 2009).

$\mathrm{P}_{6}$ : Scholarly fragmentation diminishes disciplinary credibility with external audiences.

$\mathrm{P}_{7}$ : Analogizing from evolutionary theory (Wilson \& Wilson, 2007), competition for status within paradigms beats cooperation, but cooperative and cohesive paradigms beat paradigms experiencing competition from within. Therefore,

$\mathrm{P}_{8}$ : Fragmentation (as opposed to specialization, or of maverick inquiry: Weisberg \& Muldoon, 2009) hinders scientific progress in primarily peer-influenced fields, and promotes progress in fields with stronger reality-based signals (Balietti, Mäs \& Helbing, 2015).

At some level or another, most scholars seek attention in an economy of limited attention span and access. Such attention is sought through payoffs such as promotions, tenure, teaching evaluations, leadership, awards, publication or grants, each of which represents instrumental values comprising forms of leverage in securing other more terminal values. As such, scholars may be analogized to players in an elaborate multi-party game, all of whom are competing through their various moves for contingent and valued outcomes. Playing on a massive field of play makes competition extremely challenging. Players carve up the field as a way of placing bigger ducks in smaller ponds, so that power can be consolidated at the small scale in order to establish the grounds for broader-scale coalitions and competition. A radical implication of the academic game analogue is the prospect that pursuing a desired standard of living through academic games often reveals truth and liberates societal opportunities as a by-product of the game. More formally, to the extent that scholarly disciplines are progressive, their progress derives as a by-product of playing truth games in the pursuit of a desired standard of living.

\section{Let the Games Begin: Future Implications}

Game theory and the analogy of games have broad applications in social science (Swedberg, 2001). The game analogy developed here need not be tethered to a particular ontology (e.g., Henrich et al., 2005), or to particular games (e.g., chicken, prisoners dilemma, stag hunt; Crawford, 2016), although as the analogy is further pursued, it is likely that certain features of academe will be modeled well by particular games (e.g., Mintzberg, 1985). The game features of several academic processes have already been explored, including government regulation of higher education (Kauko \& Niklasson, 1996), science education (Clough, 2000), higher education governance (Greenhalgh, 2015), university branding (Aula, Tienari \& Wæraas, 2015), faculty development (Lee \& McWilliam, 2008), ethical decision making (Medeiros et al., 2015), gender performance and leadership in higher education (Acker, 2010), graduate student seminar socialization (Fejes, Johansson, \& Dahlgren, 2005), medical school recruitment and education (Brosnan, 2010; Hill, Bowman, Stalmeijer, \& Hart, 2014), and the move to metricization (Grant \& Fogatry, 1998; Kelly \& Burrows, 2012) or audit culture (Spurling, 2015) in faculty evaluation. Related game-theoretic analyses have been applied to student acculturation to higher education (Bathmaker, Ingram, \& Waller, 2013; Tønseth, 2015), tenure (Chatteree \& Marshall, 2014; Grubbs \& Taylor, 2013), publishing (Faria, 2005) post-tenure activities (Faria \& Monteiro, 2008) and scientific norms of theory choice (Zamora-Bonilla, 2010).

At the more general level, Bourdieu (1998) proposed that "most human behaviors take place within playing fields" (p. 81), including social, scientific, artistic, political and bureaucratic fields. In such playing fields, agents pursue 
"quasi-magical" (p. 102) symbolic capital such as charisma, deriving from "socially constituted "collective expectations" " of others (p. 102). Others, such as Foucault $(1987,1997)$, characterized academe as a set of performative truth games revealing various relations of power in regard to self-as-subject (e.g., Hassett, 2010; Peters, 2004; Prasad, 2013; Zhao, 2012). Despite these various forays, academe has generally been treated rather peripherally as a game, rather than viewing games as a primary lens through which the academy might be understood (cf., Leahy, 2012).

Some have flirted with the game analogy, yet rarely explored its more expansive or literal implications (e.g., Collins \& Yearley, 1992). The academic game-theoretic analogue (GTA) proposed here provides a radical alternative to traditional histories of the communication field in particular (e.g., Delia, 1987; Wahl-Jorgensen, 2004), and general theories of disciplinary change, which generally focus on either intellectual or political historiographies. From the GTA perspective, academic life is only one among a potentially infinite number of games. In this instance, scholars, students, teachers and administrators have identified and co-evolved a game that provides a variety of admirable and desirable forms of capital (Chatterjee \& Marshall, 2014; Doerr, 2004; Faria \& Monteiro, 2008; Grubbs \& Taylor, 2013; Nevo \& Nevo, 1989; Wolfinger, et al., 2009). It is reasonable to assume that scholars have the same types of interests as ordinary persons: "they prefer more income, more power, and more comfortable jobs; but they also seem to fiercely pursue fame and honors" and "scientific capital" or "credit" (Zamora-Bonilla, 2010, p. 298). The academy provides a generally habitable environment for the pursuit of such a utility function, filled with vibrant dialogue, reasonable compensation, broad degrees of discretion in scheduling, individual office spaces, good health and retirement benefits, and an increasingly rare form of capital - tenure. For those who strategically play the game competently, such forms of capital are available, along with a variety of additional status tokens (e.g., social affirmation through student and peer evaluations, awards, hierarchical status progression milestones, etc.). It is an attractive game - a game that may happen to promote understandings of the nature of communication, or whichever topics or fields of play to which the game is extended.

Game theory analogues have the potential to provide an architectonic or a 'meta/meta-theoretical' perspective toward paradigm development (Simonson, García-Jiménez, Siebers \& Craig, 2013) by attempting to explain attempts to explain attempts to explain. There are other, more reflexive, implications. For one, such a perspective may be more ontological than epistemological. Huizinga (1949) characterized our species as homo ludens, or the human that plays. The cognitive revolution of homo sapiens began with language capacity that allowed them "to play an astounding variety of games. Thanks to their ability to invent fiction, Sapiens create more and more complex games, which each generation develops and elaborates even further" (Harare, 2015, p. 19).

A second set of implications follows from the prospect of simulating or testing some game models of academic politics. As with moral dilemma and game studies, identifying faculty preferences for various payoffs and risks (e.g., 1 high impact publication vs. 3 low impact publications, a large grant vs. a teaching award) might begin to reveal game styles and strategies. Formulating actual game scenarios could itself begin to excavate game-like structures in the academy.

A final reflexive implication concerns a self-awareness of the game - does it change a player's attitude to work if they think of it as a game, or does it merely provide another interesting interpretive angle on routines to which they are already habituated? Does self-awareness of the game change the nature of the game itself? Is the cautionary aphorism, that the reason that academic politics are so vicious is because the stakes are so small (QuoteInvestigator, 2013), a symptom of gamification that has already infected the academy? Perhaps a clearer sense of the game(s) of academe may ironically lead closer to fruition of Foucault's (1997) "utopian" conjecture that "in a society where communication has reached a high level of transparency, games of truth are perhaps more independent of structures of power" (p. 298). Whether this analogue inflames or tames the game remains to be seen.

\section{References}

Aaltio, I. (2009). How to become a knowledge holder: Creating a piece of scientific knowledge with originality. Tamara Journal for Critical Organization Inquiry, 7(3/4), 9-25.

Abbott, A., Cyranoski, D., Jones, N., Maher, B., Schiermeier, Q., \& Van Noorden, R. (2010). Metrics: Do metrics matter? Nature, 465(7300), 860-862. https://doi.org/10.1038/465860a

Acker, S. (2010). Gendered games in academic leadership. International Studies in Sociology of Education, 20(2), 129-152. https://doi.org/10.1080/09620214.2010.503062

Aguinis, H., \& O'Boyle, E. J. (2014). Star performers in twenty-first century organizations. Personnel Psychology, 67(2), 313-350. https://doi.org/10.1111/peps.12054

Alexander, J. C., \& Colomy, P. (1992). Traditions and competition: Preface to a postpositivist approach to knowledge cumulation. In G. Ritzer (Ed.), Metatheorizing (pp. 27-52). Newbury Park, CA: Sage.

Altman, I., \& Rogoff, B. (1987). World's view in psychology: Trait, interactional, organismic, transactional perspectives. In D. Stokols, \& I. Altman (Eds.), Handbook of Environmental Psychology (Vol. 1, pp. 7-40). New York, NY: John 
Wiley \& Sons.

Anderson, J. A., \& Baym, G. (2004). Philosophies and philosophic issues in communication, 1995-2004. Journal of Communication, 54, 589-615.

Anonymous. (1987). The publication game: Beyond quality in the search for a lengthy vitae. Journal of Social Behavior and Personality, 2, 3-12.

Anonymous. (1991). The publication game II: Editorial confrontation, or how to browbeat editors. Journal of Social Behavior and Personality, 6, 1-6.

Aula, H., Tienari, J., \& Wæraas, A. (2015). The university branding game. International Studies of Management \& Organization, 45(2), 164-179. https://doi.org/10.1080/00208825.2015.1006015

Azoulay, P., Fons-Rosen, C., \& Graff, Z. J. S. (2015). Does science advance one funeral at a time? (National Bureau of Economic Research Working Paper, No. 21788). Cambridge, MA. https://doi.org/10.3386/w21788

Balietti, S., Mäs, M., \& Helbing, D. (2015). On disciplinary fragmentation and scientific progress. Plos ONE, 10(3), 1-26. https://doi.org/10.1371/journal.pone.0118747

Barash, D. P. (2003). The survival game: How game theory explains the biology of cooperation and competition. New York, NY: Henry Holt.

Barnett, G., Huh, C., Kim, Y., \& Park, H. (2011). Citations among communication journals and other disciplines: A network analysis. Scientometrics, 88(2), 449-469. https://doi.org/10.1007/s11192-011-0381-2

Bathmaker, A., Ingram, N., \& Waller, R. (2013). Higher education, social class and the mobilisation of capitals: Recognising and playing the game. British Journal of Sociology of Education,34(5-6), 723-743. https://doi.org/10.1080/01425692.2013.816041

Bishop, J. D. (2006). Moral intuitions versus game theory: A response to Marcoux on résumé embellishing. Journal of Business Ethics, 67(2), 181-189. https://doi.org/10.1007/s10551-006-9022-8

Blokland, H. (2015). Creating useable knowledge for tomorrow's democratic societies: The academic background of social science works (position paper). Potsdam: Social Science Works. http://socialscienceworks.org/wp-content/uploads/2015/02/Blokland-Hans.-2015-The-Academic-Background-of-S ocial-Science-Works.pdf

Bohannon, J. (2013). Who's afraid of peer review? Science, 342(6154), 60-65. https://doi.org/10.1126/science.342.6154.60

Bostrom, R., \& Donohew, L. (1992). The case for empiricism: Clarifying fundamental issues in communication theory. Communication Monographs, 59, 109-129. https://doi.org/10.1080/03637759209376256

Bourdieu, P. (1998). Practical on the theory reason of action. Stanford, CA: Stanford University Press.

Brosnan, C. (2010). Making sense of differences between medical schools through Bourdieu's concept of field. Medical Education, 44(7), 645-652. https://doi.org/10.1111/j.1365-2923.2010.03680.x

Campbell, D. T. (1993). Plausible coselection of belief by referent: All the "objectivity" that is possible. Perspectives on Science, 1, 88-108.

Charland, M. (2003). The incommensurability thesis and the status of knowledge. Philosophy and Rhetoric, 36, $248-263$. https://doi.org/10.1353/par.2003.0024

Chatterjee, K., \& Marshall, R. C. (2014). A game-theoretic model of tenure. In K. Chatterjee \& W. Samuelson (Eds.) Game theory and business applications $\left(2^{\text {nd }}\right.$ ed., International Series in Operations Research and Management Science, Vol. 194, pp. 287-305). New York, NY: Springer. https://doi.org/10.1007/978-1-4614-7095-3_11

Chow, S. L. (1992). Acceptance of a theory: Justification or rhetoric? Journal for the Theory of Social Behaviour, 22, 447-474. https://doi.org/10.1111/j.1468-5914.1992.tb00227.x

Clark, A. M., \& Thompson, D. R. (2013). Succeeding in research: Insights from management and game theory. Journal of Advanced Nursing, 69(6), 1221-1223. https://doi.org/10.1111/jan.12061

Clarke, M. (2009). Plodders, pragmatists, visionaries and opportunists: Career patterns and employability." Career Development International, 14, 8-28. https://doi.org/10.1108/13620430910933556

Clough, M. P. (2000). The nature of science: Understanding how the game of science is played. Clearing House, 74(1), 13-17. https://doi.org/10.1080/00098655.2000.11478631

Collins, H. M., \& Yearley, S. (1992). Epistemological chicken. In A. Pickering (Ed.), Science as practice and culture 
(pp. 301-326). Chicago, IL: University of Chicago Press.

Craig, R. T. (1999). Communication as a field. Communication Theory, 9, 119-161. https://doi.org/10.1111/j.1468-2885.1999.tb00355.x

Crawford, V. P. (2016). New directions for modelling strategic behavior: Game-theoretic models of communication, coordination, and cooperation in economic relationships. Journal of Economic Perspectives, 30(4), 131-150. https://doi.org/10.1257/jep.30.4.131

Csikszentmihalyi, M. (1990). Flow. New York, NY: Harper \& Row.

Czubaroff, J. (1989). The deliberative character of strategic scientific debates. In H. W. Simons (Ed.), Rhetoric in the human sciences (pp. 28-47). Newbury Park, CA: Sage.

Dance, F. E. X. (1982). Human communication theory. New York, NY: Harper \& Row.

Delia, J. G. (1987). Communication research: A history. In C. R. Berger \& S. H. Chaffee (Eds.), Handbook of communication science (pp. 20-98). Newbury Park, CA: Sage.

Doerr, B. (2004). European tenure games. Theoretical Computer Science, 313(3), 339. https://doi.org/10.1016/j.tcs.2002.10.001

Eadie, W. F. (2011). Stories we tell: Fragmentation and convergence in communication disciplinary history. Review of Communication, 11, 161-176.

Edwards, M. A., \& Roy, S. (2017). Academic research in the 21st century: Maintaining scientific integrity in a climate of perverse incentives and hypercompetition. Environmental Engineering Science,34(1), 51-61. https://doi.org/10.1089/ees.2016.0223

Fanelli, D. (2009). How many scientists fabricate and falsify research? A systematic review and meta-analysis of survey data. Plos One, 4(5), e5738. https://doi.org/10.1371/journal.pone.0005738

Faria, J. R. (2005). The game academics play: Editors versus authors. Bulletin of Economic Research, 57(1), 1-12. https://doi.org/10.1111/j.1467-8586.2005.00212.X

Faria, J. R., \& Monteiro, G. (2008). The tenure game: Building up academic habits. Japanese Economic Review, 59(3), 370-380. https://doi.org/10.1111/j.1468-5876.2008.00423.x

Fejes, A., Johansson, K., \& Dahlgren, M. (2005). Learning to play the seminar game: Students' initial encounters with a basic working form in higher education. Teaching in Higher Education, 10(1), 29-41. https://doi.org/10.1080/1356251052000305516

Feyerabend, P. (1980). How to defend society against science. In E. D. Klemke, R. Hollinger, \& A. D. Kline (Eds.), Introductory readings in the philosophy of science (pp. 55-65). Buffalo, NY: Prometheus.

Ford, J. (1975). Paradigms \& fairy tales: An introduction to the science of meanings (Vol. 1). London: Routledge \& Kegan Paul.

Foucault, M. (1987). J. D. Gauthier (Interviewer): The ethic of care for the self as a practice of freedom: An interview with Michel Foucault on January 20, 1984. Philosophy \& Social Criticism, 12, 112-131. https://doi.org/10.1177/019145378701200202

Foucault, M. (1988). Technologies of the self. In L. H. Martin, H. Gutman, \& P. H. Hutton (Eds.), Technologies of the self: A seminar with Michel Foucault (pp. 16-49). Amherst, MA: University of Massachusetts Press.

Foucault, M. (1997). In P. Rabinow, R. Hurley et al. (Eds.), Ethics: Subjectivity and truth: The essential works (Vol. 1). London, England: Allen Lane/Penguin Press.

Goffman, E. (1969). Strategic interaction. Philadelphia, PA: University of Pennsylvania Press.

Goldie, D., Linick, M., Jabbar, H., \& Lubienski, C. (2014). Using bibliometric and social media analyses to explore the "echo chamber" hypothesis. Educational Policy, 28(2), 281-305. https://doi.org/10.1177/0895904813515330

Gould, S. J., \& Lewontin, R. C. (1979). The spandrels of San Marco and the panglossian paradigm: A critique of the adaptationist programme." Proceedings of the Royal Society of London-B, 205, 581-598. https://doi.org/10.1098/rspb.1979.0086

Graham, G. A. (1974). Ethical guidelines for public administrators: Observations on rules of the game. Public Administration Review, 34(1), 90-92. https://doi.org/10.2307/974407

Grant, J., \& Fogarty, T. (1998). Faculty evaluation as a social dilemma: A game theoretic approach. Accounting Education, 7(3), 225-248. https://doi.org/10.1080/096392898331162 
Green, C. D. (2015). Why psychology isn't unified, and probably never will be. Review of General Psychology, 19(3), 207-214. https://doi.org/10.1037/gpr0000051

Greenhalgh, T. (2015). Higher education governance as language games: A Wittgensteinian case study of the breakdown of governance at the London School of Economics 2004-2011. Higher Education Quarterly, 69(2), 193-213. https://doi.org/10.1111/hequ.12064

Grinell, S., \& Rabin, C. (2013). Modern education: A tragedy of the commons. Journal of Curriculum Studies, 45(6), 748-767. https://doi.org/10.1080/00220272.2013.813079

Grubbs, M. R., \& Taylor, P. A. (2013). Who has the most skin in the game? A stake owner theory of tenure. Academy of Educational Leadership Journal, 17(2), 121-133.

Grüne-Yanoff, T. (2011). Models as products of interdisciplinary exchange: Evidence from evolutionary game theory. Studies in History \& Philosophy of Science Part A, 42(2), 386-397.

https://doi.org/10.1016/j.shpsa.2010.12.004

Guntau, M., \& Laitko, H. (1991). On the origin and nature of scientific disciplines. In W. R. Woodward \& R. S. Cohen (Eds.), World views and scientific discipline formation (Vol. 134, Boston Studies in the Philosophy of Science, pp. 17-28). Boston: Kluwer Academic. https://doi.org/10.1007/978-94-011-3164-3_2

Harare, Y. N. (2015). Sapiens: A brief history of humankind. New York, NY: HarperCollins.

Hassett, D. D. (2010). Technologies and truth games: Research as a dynamic method. Language Arts, 87(6), 457-464.

Hawes, L. (1975). Pragmatics of analoguing: Theory and model construction in communication. Reading, MA: Addison-Wesley.

Henrich, J., Boyd, R., Bowles, S., Camerer, C., Fehr, E., Gintis, H., \& ... Tracer, D. (2005). 'Economic man' in cross-cultural perspective: Behavioral experiments in 15 small-scale societies. Behavioral and Brain Sciences, 28(6), 795-855. https://doi.org/10.1017/S0140525X05000142

Hill, E., Bowman, K., Stalmeijer, R., \& Hart, J. (2014). You've got to know the rules to play the game: How medical students negotiate the hidden curriculum of surgical careers. Medical Education, 48(9), 884-894. https://doi.org/10.1111/medu.12488

Huizinga, J. (1949). Homo ludens: A study of the play-element in culture. London, England: Routledge \& Kegan Paul.

Hunt, H. T. (2005). Why psychology is/is not traditional science: The self-referential bases of psychological research and theory. Review of General Psychology, 9(4), 358-374. https://doi.org/10.1037/1089-2680.9.4.358

Hynes, M., Sharpe, S., \& Greig, A. (2011). Appearing true in the social sciences: Reflections on an academic hoax. Journal of Sociology, 48, 287-303. https://doi.org/10.1177/1440783311413487

Irzik, G., \& Grünberg, T. (1995). Carnap and Kuhn: Arch enemies or close allies? British Journal for the Philosophy of Science, 46, 285-307. https://doi.org/10.1093/bjps/46.3.285

Jacobs, J. A., \& Frickel, S. (2009). Interdisciplinarity: A critical assessment. Annual Review of Sociology, 35, 43-65. https://doi.org/10.1146/annurev-soc-070308-115954

Janssen, M. A., \& Rollins, N. D. (2012). Evolution of cooperation in asymmetric commons dilemmas. Journal of Economic Behavior \& Organization, 81(1), 220-229. https://doi.org/10.1016/j.jebo.2011.10.010

Jost, J. T., \& Kruglanski, A. W. (2002). The estrangement of social constructionism and experimental social psychology: History of the rift and prospects for reconciliation. Personality and Social Psychology Review, 6, 168-187. https://doi.org/10.1207/S15327957PSPR0603_1

Kauko, J. (2013). Dynamics in higher education politics: A theoretical model. Higher Education: The International Journal of Higher Education and Educational Planning, 65(2), 193-206. https://doi.org/10.1007/s10734-012-9538-z

Kelly, A., \& Burrows, R. (2011). Measuring the value of sociology? Some notes on performative metricization in the contemporary academy. Sociological Review, 59(Suppl 2), 130-150. https://doi.org/10.1111/j.1467-954X.2012.02053.x

Klamer, A., \& van Dalen, H. P. (2002). Attention and the art of scientific publishing. Journal of Economic Methodology, 9(3), 289-315. https://doi.org/10.1080/1350178022000015104

Knorr-Cetina, K. (1999). Epistemic cultures: How the sciences make knowledge. Cambridge, MA: Harvard University Press 
Korzybski, A. (1933). Science and sanity: An introduction to non-Aristotelian systems and general semantics. Lancaster, PA: International Non-Aristotelian Library Publishing.

Kuhn, T. S. (1970). Postscript-1969. The structure of scientific revolutions (2nd ed.). Chicago, IL: University of Chicago.

Kuhn, T. S. (2000). The road since structure: Philosophical essays, 1970-1993. Chicago, IL: University of Chicago.

Laudan, L., Donovan, A., Laudan, R., Barker, P., Brown, H., Leplin, J., Thagard, P., \& Wykstra, S. (1986). Scientific change: Philosophical models and historical research. Synthese, 69, 141-223. https://doi.org/10.1007/BF00413981

Leahy, S. M. (2012). The barbarians at the gate. Playing the higher education game: Observations from the periphery of the field. Journal of Further \& Higher Education, 36(2), 169-185. https://doi.org/10.1080/0309877X.2011.606899

Lee, A., \& McWilliam, E. (2008). What game are we in? Living with academic development. International Journal for Academic Development, 13(1), 67-77. https://doi.org/10.1080/13601440701860284

Lynch, M. (1992). Extending Wittgenstein: The pivotal move from epistemology to the sociology of science. In A. Pickering (Ed.), Science as practice and culture (pp. 215-265). Chicago, IL: University of Chicago Press.

Lyotard, J. F., \& Thébaud, J. L. (1985). Just gaming (transl. W. Godzich). Minneapolis, MN: University of Minnesota Press.

Marcoux, A. M. (2006). A counterintuitive argument for résumé embellishment. Journal of Business Ethics, 63(2), 183-194. https://doi.org/10.1007/s10551-005-2412-5

Martin, T. W. (2007, Sept/Oct.). Scientific literacy and the habit of discourse. Seed, 76-77.

Mayo, D. G. (1996). Ducks, rabbits, and normal science: Recasting the Kuhn's-eye view of Popper's demarcation of science. British Journal for the Philosophy of Science, 47, 271-290. https://doi.org/10.1093/bjps/47.2.271

Mayo-Wilson, C., Zollman, K., \& Danks, D. (2013). Wisdom of crowds versus groupthink: Learning in groups and in isolation. International Journal of Game Theory, 42(3), 695-723. https://doi.org/10.1007/s00182-012-0329-7

Medeiros, K. E., Gibson, C., Mecca, J. T., Giorgini, V., Connelly, S., \& Mumford, M. D. (2015). Playing, sitting out, and observing the game: An investigation of faculty members' perspectives on political behavior in ethical decision making. Accountability in Research: Policies \& Quality Assurance, 22(5), 284-300. https://doi.org/10.1080/08989621.2014.989219

Merton, R. K. (1973). Paradigm for the sociology of knowledge. In R. K. Merton (Ed.), The sociology of science: Theoretical and empirical investigations (pp. 7-40). Chicago, IL: University of Chicago Press.

Mintzberg, H. (1985). The organization as political arena. Journal of Management Studies, 22(2), $133-154$. https://doi.org/10.1111/j.1467-6486.1985.tb00069.x

Moldoveanu, M. (2002). Language, games and language games. Journal of Socio-Economics, 31(3), $233-251$. https://doi.org/10.1016/S1053-5357(02)00118-X

Motes, W. H. (1989). What our doctoral students should know about the publishing game. Journal of Marketing Education, 11(1), 22. https://doi.org/10.1177/027347538901100105

Mulnix, M. W., Cojanu, K., \& Pettine, S. B. (2011). Critical role of the dominant coalition in higher education marketing strategy formulation. Research in Higher Education, 11, 1-10.

Nash, U. W. (2014). The curious anomaly of skewed judgment distributions and systematic error in the wisdom of crowds. Plos ONE, 9(11). https://doi.org/10.1371/journal.pone.0112386

Nevo, O., \& Nevo, B. (1996). The promotion game. Journal of Personnel Evaluation in Education, 10(2), $173-177$. https://doi.org/10.1007/BF00156897

Niklasson, L. (1996). Game-like regulation of universities: Will the new regulatory framework for higher education in Sweden work? Higher Education, 32(3), 267. https://doi.org/10.1007/BF00138867

O'Boyle, E., Jr., \& Aguinis, H. (2012). The best and the rest: Revisiting the norm of normality of individual performance. Personnel Psychology, 65, 79-110. https://doi.org/10.1111/j.1744-6570.2011.01239.x

Park, H. W., \& Leydesdorff, L. (2009). Knowledge linkage structures in communication studies using citation analysis among communication journals. Scientometrics, 81, 157-175. https://doi.org/10.1007/s11192-009-2119-y

Peters, M. A. (2004). Educational research: 'Games of truth' and the ethics of subjectivity. Journal of Educational Enquiry, 5, 50-63.

Pievani, T., \& Serrelli, E. (2011). Exaptation in human evolution: How to test adaptive vs axaptive evolutionary 
hypotheses. Journal of Anthropological Sciences, 89, 1-15. https://doi.org/10.4436/jass.89-015

Planck, M. (1949). Scientific autobiography and other papers (trans. F. Gaynor). New York, NY: Philosophical Library.

Popper, K. (1974). The problem of demarcation. In D. Miller (Ed.), Popper selections (pp. 118-130). Princeton, NJ: Princeton University.

Popper, K. (1980). Science: Conjectures and refutations. In E. D. Klemke, R. Hollinger, \& A. D. Kline (Eds.), Introductory readings in the philosophy of science (pp. 19-34). Buffalo, NY: Prometheus.

Prasad, A. (2013). Playing the game and trying not to lose myself: A doctoral student's perspective on the institutional pressures for research output. Organization, 20(6), 936-948. https://doi.org/10.1177/1350508413486274

Prelli, L. J. (1989). A rhetoric of science: Inventing scientific discourse. Columbia, SC: University of South Carolina.

Puddephatt, A. J., \& McLaughlin, N. (2015). Critical nexus or pluralist discipline? Institutional ambivalence and the future of Canadian sociology. Canadian Review of Sociology, 52(3), 310-332. https://doi.org/10.1111/cars.12079

Quote Investigator. (2013, August 18). Academic politics are so vicious because the stakes are so small. Retrieved: December 15, 2017: https://quoteinvestigator.com/2013/08/18/acad-politics/

Ritzer, G., Zhao, S., \& Murphy, J. (2001). Metatheorizing in sociology: The basic parameters and the potential contributions of postmodernism. In J. H. Turner (Ed.), Handbook of sociological theory (pp. 113-131). New York: Kluwer/Plenum. https://doi.org/10.1007/0-387-36274-6_6

Salomón, Y. P. (2010). The scientific field of Communication: Examining its intellectual structure through cocitation analysis. Revista Latina De Comunicación Social, 13(65), 1-9. https://doi.org/10.4185/RLCS-65-2010-893-204-213-EN

Schneider, D. J. (1992). Publication games: Reflections on Reis and Stiller. Personality and Social Psychology Bulletin, 18(4), 498-503. https://doi.org/10.1177/0146167292184016

Simonson, P., García-Jiménez, L., Siebers, J., \& Craig, R. T. (2013). Some foundational conceptions of communication: Revising and expanding the traditions of thought. Empedocles: European Journal for the Philosophy of Communication, 4(1), 73-92. https://doi.org/10.1386/ejpc.4.1.73_1

Smaldino, P. E., \& McElreath, R. (2016. The natural selection of bad science. Royal Society of Open Science, 3(160384), 1-17. https://doi.org/10.1098/rsos.160384

Smith, T. J. III. (1988). Diversity and order in communication theory: The uses of philosophical analysis. Communication Quarterly, 36, 28-40. https://doi.org/10.1080/01463378809369705

Solomon, M. (2006). Groupthink versus the wisdom of crowds: The social epistemology of deliberation and dissent. Southern Journal of Philosophy, 44, 28-42. https://doi.org/10.1111/j.2041-6962.2006.tb00028.x

Spurling, N. (2015). Differential experiences of time in academic work: How qualities of time are made in practice. Time \& Society, 24(3), 367-389. https://doi.org/10.1177/0961463X15575842

Stanfill, M. (2012). Finding birds of a feather: Multiple memberships and diversity without divisiveness in communication research. Communication Theory, 22(1), 1-24. https://doi.org/10.1111/j.1468-2885.2011.01395.x

Swedberg, R. (2001). Sociology and game theory: Contemporary and historical perspectives. Theory and Society, 30, 301-335. https://doi.org/10.1023/A:1017532512350

Tønseth, C. (2015). Adults in the 'new' competence regime - Acquiring 'the sense of the game'. New Horizons in Adult Education \& Human Resource Development, 27(4), 4-18. https://doi.org/10.1002/nha3.20119

Tsou, J. Y. (2003). Reconsidering Feyerabend's “anarchism.” Perspectives on Science, 11, 208-235. https://doi.org/10.1162/106361403322495894

Turner, J. H. (1990). The misuse and use of metatheory. Sociological Forum, 5, 37-53. https://doi.org/10.1007/BF01115136

van Doorn, G. S., Edelaar, P., \& Weissing, F. J. (2009). On the origin of species by natural and sexual selection. Science, 326(5960), 1704-1707. https://doi.org/10.1126/science.1181661

Varga, A. (2011). Measuring the semantic integrity of scientific fields: A method and a study of sociology, economics and biophysics. Scientometrics, 88(1), 163-177. https://doi.org/10.1007/s11192-011-0342-9

Varoufakis, Y. (2008). Game theory: Can it unify the social sciences? Organization Studies, 29(8/9), 1255-1277. https://doi.org/10.1177/0170840608094779 
Wahl-Jorgensen, K. (2004). How not to found a field: New evidence on the origins of mass communication research. Journal of Communication, 54, 547-564. https://doi.org/10.1111/j.1460-2466.2004.tb02644.x

Walker, T. C. (2010). The perils of paradigm mentalities: Revisiting Kuhn, Lakatos, and Popper. Perspectives on Politics, 8, 433-451. https://doi.org/10.1017/S1537592710001180

Wang, G. (2014). Culture, paradigm, and communication theory: A matter of boundary or commensurability. Communication Theory, 24, 373-393. https://doi.org/10.1111/comt.12045

Weisberg, M., \& Muldoon, R. (2009). Epistemic landscapes and the division of cognitive labor. Philosophy of Science, 76, 225-252. https://doi.org/10.1086/644786

Wilson, D. S., \& Wilson, E. O. (2007). Rethinking the theoretical foundation of sociobiology. Quarterly Review of Biology, 82, 327-348. https://doi.org/10.1086/522809

Wischniewski, J., Windmann, S., Juckel, G., \& Brüne, M. (2009). Rules of social exchange: Game theory, individual differences and psychopathology. Neuroscience and Biobehavioral Reviews, 33(3), 305-313. https://doi.org/10.1016/j.neubiorev.2008.09.008

Wolfinger, N. H., Mason, M. A., \& Goulden, M. (2009). Stay in the game: Gender, family formation and alternative trajectories in the academic life course. Social Forces, 87(3), 1591-1621. https://doi.org/10.1353/sof.0.0182

Wray, K. B. (2011). Kuhn's evolutionary social epistemology. Cambridge, UK: Cambridge University Press. https://doi.org/10.1017/CBO9780511997990

Zagare, F. C., \& Slantchev, B. L. (2012). Game theory and other modeling approaches. In S. McLaughlin Mitchell, P. F. Diehl, \& J. D. Morrow (Eds.), Guide to the scientific study of international processes (pp. 23-41). West Sussex, UK: Wiley-Blackwell.

Zamora-Bonilla, J. (2010). Science: The rules of the game. Logic Journal of the IGPL, 18(2), 294-307. https://doi.org/10.1093/jigpal/jzp065

Zamora-Bonilla, J. P. (2006). Science studies and the theory of games. Perspectives on Science, 14(4), 525-557. https://doi.org/10.1162/posc.2006.14.4.525

Zhao, G. (2012). Human science for human freedom? Piaget's developmental research and Foucault's ethical truth games. Educational Studies: Journal of the American Educational Studies Association, 48(5), 450-464. https://doi.org/10.1080/00131946.2011.647151

\section{Copyrights}

Copyright for this article is retained by the author(s), with first publication rights granted to the journal.

This is an open-access article distributed under the terms and conditions of the Creative Commons Attribution license which permits unrestricted use, distribution, and reproduction in any medium, provided the original work is properly cited. 